\title{
Cell Populations in the Endocrine Pancreas of Human Neonates and Infants
}

\author{
J. Rahier, J. Wallon, and J.-C. Henquin \\ Department of Pathology and Unité de Diabète et Croissance, University of Louvain School of Medicine, Brussels, Belgium
}

\begin{abstract}
Summary. Pancreases from normoglycaemic neonates ( $<15$ days), infants ( 6 months) and adults were examined using immunoperoxidase techniques. Sections taken from five regions of the gland were analysed by morphometry. The volume density of total endocrine tissue was found to be higher than previously reported: $15 \%$ in neonates, $6-7 \%$ in infants and $2-3 \%$ in adults. In neonates, many endocrine cells were located in small clusters, sometimes budding from ducts, and up to $15 \%$ were isolated in ducts and acini. Similar clusters were still present, though less frequent, in infants. The relative proportion of all cell types varied only slightly between the different regions, except in the posterior part of the head, which comprised $90 \%$ of all PP(polypeptide) cells. With age, the proportion of somatostatin cells decreased (from about $30 \%$ in neonates to about $10 \%$ in adults), that of insulin cells increased (50 to $70 \%$ ) and that of glucagon cells remained stable $(20 \%)$. In the posterior part of the head, the proportion of PP cells tended to be higher in adults than in neonates or infants. This study shows that both the endocrine cell populations and the proportion of endocrine tissue in the pancreas change markedly in early life. It also suggests that "nesidioblastosis" is a normal feature of the pancreas of normoglycaemic neonates and young infants.
\end{abstract}

Key words: Pancreas, insulin, glucagon, somatostatin, pancreatic polypeptide, neonates, infants, immunocytochemistry.

The abundance of endocrine tissue in the pancreas of infants has long been recognised [15]. However, knowledge of the relative proportions of the different cell types in the normal infant remains fragmentary $[10,13]$. Thus, the limitations of early histochemical techniques made it difficult to distinguish and quantify non-B cells $[9,11,21,25]$. Furthermore, because of limited availability of normal pancreases, most studies have been carried out on the pancreas of infants born to diabetic mothers $[26,31]$ or on specimens of pancreas removed at surgery from infants with hypoglycaemia secondary to hyperinsulinism $[7$, $9,11,21]$.

In the present study, we have systematically quantitated the different cell types of the endocrine pancreas of normoglycaemic neonates and compared their distribution with that observed in infants and adults.

\section{Material and Methods}

Pancreases were obtained, at autopsy, from 6 neonates and 3 infants born to non-diabetic mothers, and from three adults without diabetes or other pancreatic disease. The pancreas was removed within $6 \mathrm{~h}$ of death and carefully cleaned from adjacent lymph nodes, fat and vessels. The characteristics of the patients and the weight of the pancreases are given in Table 1 . Slices cut through the head, the isthmus, the corpus and the tail, were fixed for $24 \mathrm{~h}$ in Bouin-Allen's solution and embedded in paraffin.

\section{Immunocytochemistry}

Sections of $5 \mu \mathrm{m}$ thickness, were mounted on glass slides with aqueous gelatine, dried for $12 \mathrm{~h}$ at $60^{\circ} \mathrm{C}$ and processed by the peroxidase antiperoxidase technique of Sternberger [23, 24]. Guinea-pig anti-insulin serum (Dr. P. H. Wright, Indianapolis), rabbit anti-glucagon serum (K44 Novo Research Institute), rabbit anti-somatostatin serum (Dr. W. Gepts, Brussels) and rabbit antibovine pancreatic polypeptide (anti-bPP) (Dr. R. E. Chance, Indianapolis) were used at dilutions of $1 / 3000,1 / 800,1 / 20000$, and $1 / 40000$ respectively, on four successive sections from each region.

Rabbit anti-peroxidase bound to horseradish peroxidase (Dr. W. Gepts) was used at a dilution of $1 / 300$. To reveal the peroxidase, the sections were treated with a solution of $0.5 \mathrm{~g} / 13,3^{\prime}$ diaminobenzidine, supplemented with $400 \mu \mathrm{l} / \mathrm{l}$ hydrogen peroxide $(30 \%$ $\mathrm{v} / \mathrm{v})$.

In the slice cut through the head, a distinction was made between the posterior and the anterior lobes of the gland [13, 18]. The limits of the posterior lobe, particularly rich in PP-cells, were delineated on sections treated with anti-bPP serum.

A fifth section from each region was stained with hemalumeosin-saffron to evaluate the importance of the mesenchymal component. 
Table 1. Characteristics of patients

\begin{tabular}{|c|c|c|c|c|c|c|c|}
\hline & \multirow[t]{2}{*}{ Case } & \multirow[t]{2}{*}{ Age } & \multirow[t]{2}{*}{ Sex } & \multirow[t]{2}{*}{ Cause of death } & \multirow{2}{*}{$\begin{array}{l}\text { Mesenchymal tissue } \\
\text { in pancreas (\%) }\end{array}$} & \multicolumn{2}{|c|}{ Weight of pancreas $(\mathrm{g})$} \\
\hline & & & & & & Total & Epithelial \\
\hline \multirow[t]{6}{*}{ Neonates } & 1 & 4 days & $\mathbf{M}$ & Hypoplasia of right ventricle & 31.2 & 3.1 & 2.3 \\
\hline & 2. & 4 days & $\mathbf{M}$ & $\begin{array}{l}\text { Hypoplasia of left ventricle } \\
\text { and aorta }\end{array}$ & 26.2 & 2.6 & 1.9 \\
\hline & 3 & 8 days & $\mathbf{F}$ & Hypoplasia of left ventricle & 32.9 & 2.6 & 1.7 \\
\hline & 4 & 10 days & $\mathrm{F}$ & Hypoplasia of left ventricle & 25.8 & 3.3 & 2.4 \\
\hline & 5 & 10 days & $\mathbf{M}$ & Microcephaly & 26.6 & 2.9 & 2.1 \\
\hline & 6 & 15 days & $\mathbf{M}$ & Unknown & 27.5 & 2.5 & 1.8 \\
\hline \multirow[t]{3}{*}{ Infants } & 7 & 5 months & $\mathrm{F}$ & Cardiac malformation & 19.0 & 7.9 & 6.4 \\
\hline & 8 & 6 months & M & Cerebro-vascular malformation & 19.1 & 6.6 & 5.3 \\
\hline & 9 & 6 months & $\mathbf{M}$ & Broncho-pneumonia & 23.4 & 8.8 & 6.7 \\
\hline \multirow[t]{3}{*}{ Adults } & 10 & 59 years & $\mathrm{F}$ & Cerebral infarction & 18.5 & 61.5 & 50.1 \\
\hline & 11 & 69 years & $\mathrm{F}$ & Pulmonary embolism & 25.0 & 75.0 & 56.3 \\
\hline & 12 & 72 years & $\mathrm{F}$ & Myocardial infarction & 24.0 & 62.0 & 47.1 \\
\hline
\end{tabular}

\section{Morphometry}

The volume density of the different components was evaluated by the point counting method of Chalkley [4], using a 42 point lattice. Distinction was made between insular cells and endocrine cells isolated in acinar or ductular tissues. Each section was completely examined at a linear magnification of $350 \times$, by counting one field out of five, automatically selected by the Eltinor system (Jenoptik, Jena).

The volume density of a given endocrine cell type in the epithelial tissue, was obtained by the ratio of the number of hits on these endocrine cells to the number of hits on other epithelial cells (thus excluding mesenchymal tissue). Total volume density of endocrine tissue in the epithelial tissue was obtained by summation of volume densities for the four cell types.

The volume density of mesenchymal tissue was also estimated by the technique of point counting. This evaluation made it possible to express the volume density of endocrine tissue in relation to the total pancreatic tissue. It also permitted correction of the weight of the whole pancreas to be made, for the contribution of mesenchymal tissue and thus the weight of epithelial tissue to be obtained. The absolute mass of endocrine tissue was evaluated by multiplying the mean volume density by the mean weight of epithelial tissue.

The adequacy and the precision of our morphometrical techniques were evaluated as follows. In a section stained to reveal B cells, all fields were counted and the results were compared to those obtained with the usual procedure of counting one field out of five. The mean $\pm S D$ of both series proved to be similar.

In addition, the relative error $(E)$ of the estimation of the volume density $\left(\mathrm{V}_{\mathrm{v}}\right)$ of one cell type was evaluated by a formula given by Weibel [29]:

$\mathrm{E}=\sqrt{0.453 \cdot \frac{\mathrm{I}-\mathrm{V}_{\mathrm{v}}}{\mathrm{V}_{\mathrm{v}} \cdot \mathrm{P}_{\mathrm{t}}}}$

where $P_{t}$ is the number of test points (number of counted fields $\times 42$ points) in one section. For the highest values of $V_{v}$ (insulin cells in the dorsal lobe of the neonate pancreas), the calculated relative error in each section was about $6 \%$ (of a mean value of $6.5 \%$ of $\mathrm{B}$ cells). For the lowest value of $\mathrm{V}_{\mathrm{v}}$ (PP-cells in the dorsal lobe of the adult pancreas), the calculated relative error in each section was about $50 \%$ (of a mean value of $0.05 \%$ of PP-cells).
Results are presented as mean \pm SD or mean + range. Differences between means were assessed by the Wilcoxon rank-sum test.

\section{Results}

\section{Neonates}

In the neonatal pancreas, epithelial components were surrounded by abundant loose connective tissue; the mean volume density of this mesenchymal tissue was as high as $28 \%$. The endocrine cells demonstrated by the immunoperoxidase technique appeared particularly numerous. Most insulin cells were located within the islets in which they constituted a core completely surrounded by a ring of non-B cells (the socalled mantle islets). Many B cells, sometimes associated with other endocrine cells, were also grouped in small clusters, located near ductular structures or amidst acinar cells (Fig. 1 A). Less frequently (Table 2 ), isolated B cells were scattered among exocrine cells or in the ductular epithelium. The same pattern of distribution exists in the different regions of the pancreas. As shown in Table 3, the volume density of $B$ cells varied only slightly between the different regions, except in the posterior part of the head, where it was approximately $45 \%$ lower.

Glucagon cells were much less numerous than B cells. In the islets, they were located along capillaries or at the periphery, forming a thin discontinuous ring (Fig. 1B).

Rarely A cells constituted a crescent zone at one pole of the islets; they were sometimes isolated (Table 2) and exceptionally seen in small clusters. The volume density of glucagon cells was about $50 \%$ less than that of insulin cells. It was similar in the 

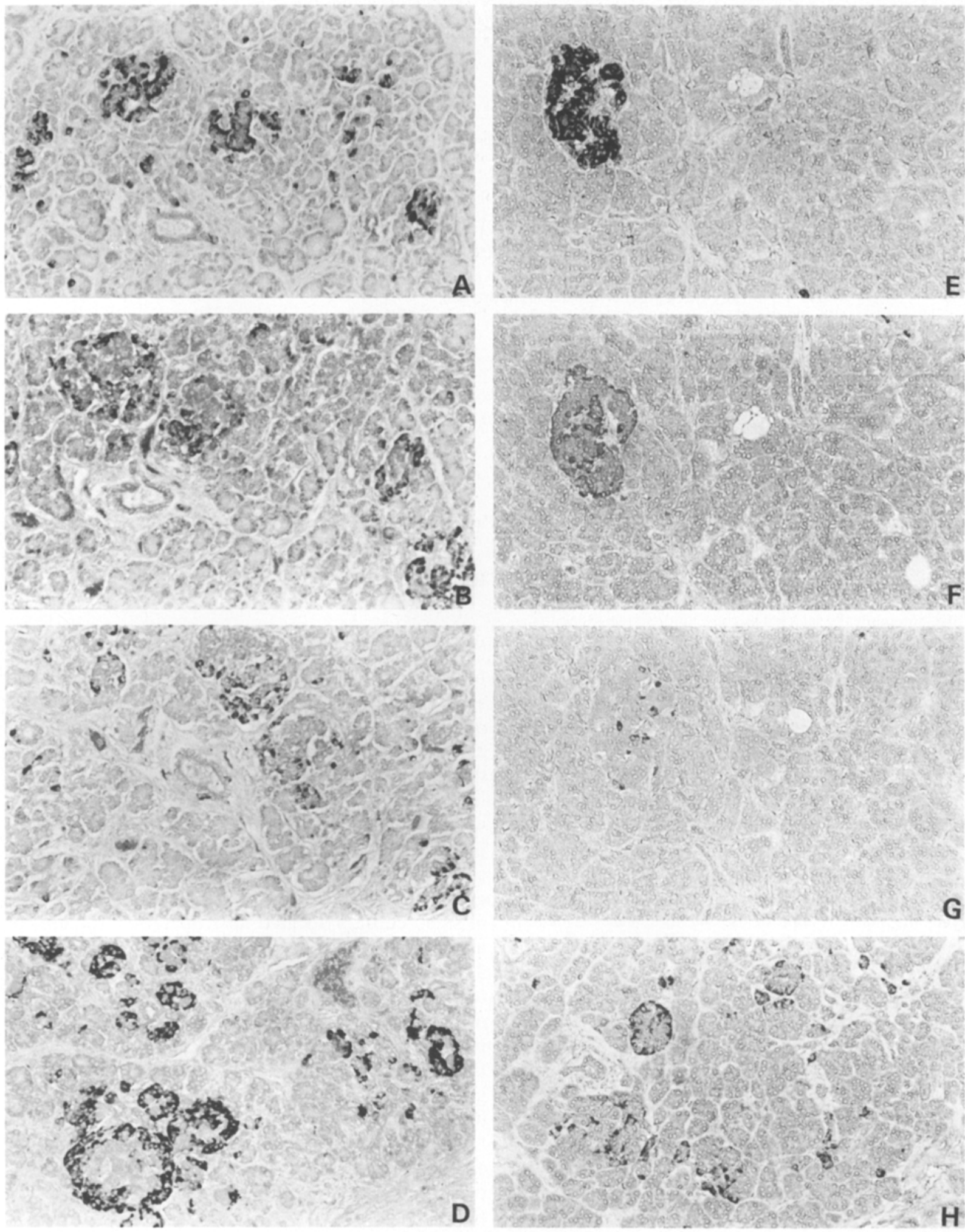

Fig. I A-H. Human pancreatic tissue processed by the peroxidase antiperoxidase technique with anti-insulin $\mathbf{A}, \mathbf{E}$, anti-glucagon B, F, antisomatostatin $\mathbf{C}, \mathbf{G}$ or anti-pancreatic polypeptide serum D, H. A-D Neonatal pancreas. $\mathbf{E}-\mathbf{H}$ Adult pancreas. $\mathbf{A}-\mathbf{C}$ and $\mathbf{E}-\mathbf{G}$ are consecutive sections from the corpus of the pancreas. $\mathbf{D}$ and $\mathbf{H}$ are sections taken from the posterior region of the head. $(\times 125)$ 
different regions of the pancreas, save in the posterior region of the head (Table 3).

Most somatostatin cells were located within islets, where their topography resembled that of glucagon cells. Sometimes they were enclosed in small clusters

Table 2. Percentage of the different endocrine cells present outside of the islets

\begin{tabular}{lcr}
\hline & $\begin{array}{l}\text { Head } \\
\text { (posterior region) }\end{array}$ & Rest of the pancreas \\
\hline Insulin cells & & \\
$\quad$ Neonates & $19.1(8.3-25.3)$ & $17.3(11.6-33.0)$ \\
Infants & $14.0(3.2-33.0)$ & $10.9(3.9-15.6)$ \\
Adults & $9.7(5.9-12.3)$ & $5.4(3.8-6.6)$ \\
Glucagon cells & & \\
Neonates & $24.4^{\mathrm{a}}$ & $10.6(4.1-22.8)$ \\
Infants & $6.3^{\mathrm{a}}$ & $4.1(2.1-6.3)$ \\
Adults & $<0.1^{\mathrm{a}}$ & $4.8(0-10.4)$ \\
Somatostatin cells & & $12.6(5.8-18.9)$ \\
Neonates & $24.7^{\mathrm{a}}$ & $8.8(7.5-9.9)$ \\
Infants & $<0.1^{\mathrm{a}}$ & $7.1(0-13.0)$ \\
$\quad$ Adults & $<0.1^{\mathrm{a}}$ & \\
Pancreatic polypeptide cells & $11.7(5.9-28.0)$ & $37.5^{\mathrm{a}}$ \\
Neonates & $11.1(0-5.3)$ & $8.3^{\mathrm{a}}$ \\
Infants & $15.1(8.3-23.5)$ & $<0.1^{\mathrm{a}}$ \\
Adults &
\end{tabular}

Values are means with the range in parentheses

a Because of the low volume densities of glucagon and somatostatin cells in the posterior region of the head and of PP cells in the rest of the pancreas, the calculated proportion of isolated cells in the respective regions has a lower precision than in the other regions of endocrine cells, or spread as single cells (Table 2) among acinar or duct cells. Their volume density was intermediate between A and B cells (Table 3 ), and, again, varied only in the posterior region of the head of the pancreas, where it was lower.

The volume density of PP cells was about 80 times higher in the posterior region of the head, than in the rest of the pancreas (Table 3). In the zone rich in PP cells, they formed a large peripheral ring in the islets, or were grouped in small clusters, irregular in shape and most frequently exclusively composed of PP cells. In the rest of the pancreas, the rare PP cells were mainly located at the periphery of islets.

The mean volume density of total endocrine tissue in the neonatal pancreas amounted to $15 \%$ of the epithelial tissue, but large differences were observed from case to case (Table 3). By contrast, there was little individual variation in the relative proportion of the four cell types. Within the same pancreas, the cellular composition of the islets was uniform in all regions, except in the posterior part of the head (Fig. 2).

\section{Infants}

In infants, the weight of the pancreas was increased 2-3 fold compared to neonates, whereas the proportion of connective tissue was decreased (Table 1). The topographical appearance of the different cells in the islets was similar to that observed at birth. Isolated cells, however, were less frequent (Table 2).

Table 3. Volume density of insulin, glucagon, somatostatin and PP cells in relation to epithelial tissue

\begin{tabular}{lrrrrr}
\hline & Head (posterior) & Head (anterior) & Isthmus & Body & Tail \\
\hline Insulin cells & & & & & \\
$\quad$ Neonates & $3.7(0.6-6.2)$ & $7.1(5.2-6.0)$ & $6.6(2.7-10.2)$ & $6.4(4.5-7.4)$ & $6.1(4.7-10.1)$ \\
$\quad$ Infants & $3.7(2.3-5.4)$ & $4.0(2.8-5.6)$ & $3.1(2.7-3.4)$ & $4.5(2.3-6.2)$ & $4.4(2.2-6.7)$ \\
$\quad$ Adults & $0.7(0.2-1.0)$ & $1.3(1.0-1.5)$ & $2.1(1.4-2.5)$ & $1.9(1.4-2.5)$ & $2.7(1.4-3.5)$ \\
Glucagon cells & & & & & \\
$\quad$ Neonates & $1.0(0-1.7)$ & $3.3(1.9-4.6)$ & $3.3(1.9-4.7)$ & $4.6(1.7-7.0)$ & $3.3(0.5-6.0)$ \\
$\quad$ Infants & $0.5(0-1.3)$ & $0.6(0.4-0.8)$ & $0.8(0.6-1.1)$ & $1.2(0.4-2.1)$ & $1.3(0.5-2.4)$ \\
$\quad$ Adults & $0.1(0-0.1)$ & $0.5(0.3-0.9)$ & $0.6(0.5-0.7)$ & $0.6(0.5-0.7)$ & $0.7(0.5-0.8)$ \\
Somatostatin cells & & & & \\
$\quad$ Neonates & $2.7(0.8-5.9)$ & $5.1(3.6-6.6)$ & $4.6(3.2-5.7)$ & $4.8(2.6-7.5)$ & $5.2(3.5-9.2)$ \\
$\quad$ Infants & $2.0(1.4-2.4)$ & $1.6(1.2-2.3)$ & $1.3(0.7-2.1)$ & $1.5(0.9-2.1)$ & $1.1(0.1-2.0)$ \\
$\quad$ Adults & $0.2(0-0.3)$ & $0.2(0.1-0.3)$ & $0.3(0.2-0.4)$ & $0.3(0.2-0.4)$ & $0.4(0.2-0.5)$ \\
Pancreatic polypeptide cells & & & & \\
$\quad$ Neonates & $8.1(4.1-17.6)$ & $0.1(0-0.3)$ & $0.1(0-0.3)$ & $<0.1$ & $0.2(0-0.3)$ \\
$\quad$ Infants & $6.4(3.5-10.8)$ & $<0.1$ & $<0.1$ & $0.1(0-0.3)$ & $<0.1$ \\
$\quad$ Adults & $1.8(1.3-2.2)$ & $<0.1$ & $<0.1$ & $<.1$ & $0.1(0-0.1)$ \\
Total & & & & 0.1 \\
$\quad$ Neonates & $15.5(6.5-20.8)$ & $15.6(11.4-19.6)$ & $14.6(8.0-20.7)$ & $15.8(9.2-22.1)$ & $14.8(8.2-25.4)$ \\
$\quad$ Infants & $12.6(8.4-18.5)$ & $6.2(4.9-8.4)$ & $5.2(3.9-6.3)$ & $7.3(2.1-10.8)$ & $6.8(3.4-10.7)$ \\
$\quad$ Adults & $2.8(2.1-3.6)$ & $2.0(1.4-2.7)$ & $3.1(2.2-3.5)$ & $2.8(2.2-3.4)$ & $3.9(2.5-4.5)$ \\
\hline
\end{tabular}

Values (in \%) are means with the range in parentheses 


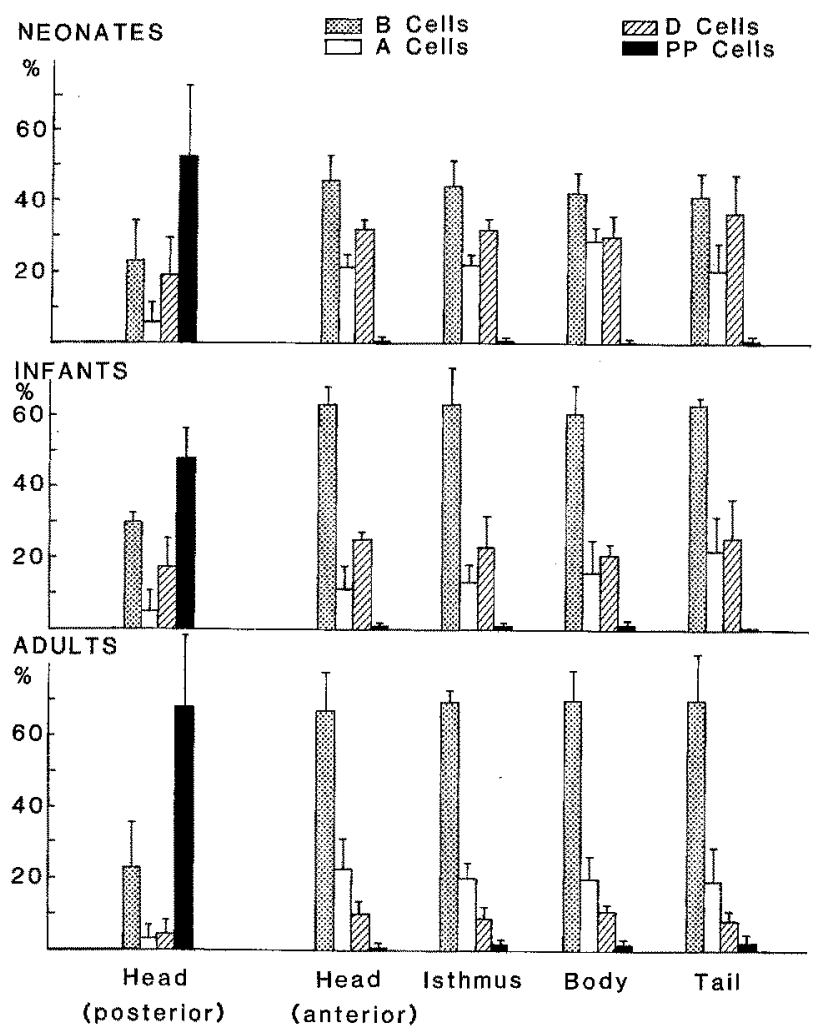

Fig. 2. Percentage of each cell type in the endocrine tissue present in the various regions of the pancreas of six neonates, three infants and three adults. Values are means $\pm \mathrm{SD}$

Small clusters of endocrine cells, budding out from ducts or isolated in the acinar tissue, were less numerous but could still be observed.

The mean volume density of total endocrine tissue in the infant varied between 5 and $7 \%$, except in the posterior part of the head, where it remained higher (Table 3). The relative proportion of the different cell types in the islets was different from that seen in neonates, at least in the region poor in PP cells (Fig. 2). The proportion of insulin cells was increased to more than $60 \%$, compared to $42 \%$ $(\mathrm{p}<0.025)$ and that of somatostatin cells was decreased to $21 \%$ compared to $34 \%(\mathrm{p}<0.025)$.

\section{Adults}

In adults, the mesenchymal tissue represented up to $25 \%$ of the whole pancreas (Table 1). However, it differed markedly from that seen in the pancreas of neonates by the presence, except in the posterior lobe of the head [17], of numerous fat cells. The endocrine cells were located almost exclusively within islets and maintained the same topographical distribution as in the infant. In the posterior part of the head, small irregular clusters of PP cells were still numerous (Fig. 1H), but clusters of other endocrine cells were no longer present in the rest of the gland. The proportion of isolated cells was also decreased (Table 2).

The mean volume density of endocrine tissue varied between 2 and $4 \%$ (Table 3 ). In the posterior part of the head, the relative proportion of PP cells was as high as $70 \%$. In the rest of the gland, the major difference from the pancreas of infants was a further decrease of the proportion of somatostatin cells $(9 \%$ compared to $21 \%, p=0.05)$.

\section{Total Mass of Endocrine Tissue}

The estimation of the weight of endocrine cells in the whole pancreas is given in Table 4 . The pancreas of neonates contained approximately $300 \mathrm{mg}$ of endocrine tissue, including about $120 \mathrm{mg}$ of B cells and $100 \mathrm{mg}$ of $\mathrm{D}$ cells. In the infant pancreas, the total mass of endocrine tissue was increased by $40 \%$, primarily because of a doubling of the mass of $B$ cells. A fivefold increase in the total weight of endocrine tissue was estimated for the adult pancreas. The major increase $(700 \%)$ was provided by the mass of $B$ cells, which amounted to about $1 \mathrm{~g}$. The smallest increase was in the mass of D cells $(40 \%)$.

\section{Discussion}

The present study shows that the mean volume density of endocrine tissue in the human neonatal pancreas amounts to $15 \%$ (Table 2). This value is twice as high as in the 3 infants of 6 months and 6-7 fold higher than in the 3 adults of this series. These volume densities of endocrine tissue are somewhat higher than the values previously reported in the literature, especially for the pancreas of neonates $[2,3$, $9,11,21]$. The neonates of this series did not suffer from erythroblastosis and were not born to mothers with overt or gestational diabetes, two conditions in which a high proportion of endocrine tissue has been described in the pancreas $[5,6,14,25,26,27,30]$. Furthermore, we never observed the abnormalities of the islets, which are classically described in neonates born to diabetic mothers [31]: enlarged islets, pleiomorphic or hyperchromatic nuclei in B cells, infiltrates of eosinophilic leucocytes, or proportion of B cells higher than $60 \%$. Therefore, the differences in proportion of endocrine tissue demonstrated by this and other studies must be accounted for by other factors.

First, contrary to most earlier studies, the present investigation was carried out with an immunoperoxidase technique. In our experience as well as in that 
Table 4. Estimated total mass of endocrine tissue

\begin{tabular}{|c|c|c|c|c|c|}
\hline & $\begin{array}{l}\text { Total } \\
\text { mg }\end{array}$ & $\begin{array}{l}\text { B cells } \\
\mathrm{mg}\end{array}$ & $\begin{array}{l}\text { A cells } \\
\mathrm{mg}\end{array}$ & $\begin{array}{l}\mathrm{D} \text { cells } \\
\mathrm{mg}\end{array}$ & $\begin{array}{l}\text { PP cells } \\
\mathrm{mg}\end{array}$ \\
\hline Neonates & $\begin{array}{l}311 \\
(225-458)\end{array}$ & $\begin{array}{l}123 \\
(94-181)\end{array}$ & $\begin{array}{l}66 \\
(46-104)\end{array}$ & $\begin{array}{l}99 \\
(65-150)\end{array}$ & $\begin{array}{l}23 \\
(13-43)\end{array}$ \\
\hline Infants & $\begin{array}{l}440 \\
(295-584)\end{array}$ & $\begin{array}{l}242 \\
(160-316)\end{array}$ & $\begin{array}{l}59 \\
(25-102)\end{array}$ & $\begin{array}{l}90 \\
(57-121)\end{array}$ & $\begin{array}{l}49 \\
(29-73)\end{array}$ \\
\hline Adults & $\begin{array}{l}1494 \\
(1146-1717)\end{array}$ & $\begin{array}{l}963 \\
(761-1097)\end{array}$ & $\begin{array}{l}261 \\
(185-355)\end{array}$ & $\begin{array}{l}137 \\
(83-187)\end{array}$ & $\begin{array}{l}133 \\
(83-190)\end{array}$ \\
\hline
\end{tabular}

Values are means with the range in parentheses

of others [9] this technique detects more endocrine cells than the older, less specific and less sensitive staining methods. Furthermore, the pancreases were studied with antisera against the four principal islet cell types.

Second, the point counting method of Chalkley [4] used in this study takes into consideration the small clusters and the isolated endocrine cells, which are disregarded with Cardell's method, commonly employed in other investigations [3, 25].

Third, in our study, the volume density of endocrine tissue was referred to the epithelial tissue, thus excluding the mesenchymal component, which may represent up to one third of the gland. Such a distinction is only exceptionally mentioned in the literature [10], but appears important because of variations of this mesenchymal tissue with age, from case to case and between the various regions of the gland.

Fourth, it is of utmost importance to define clearly the age of the patients, since the volume density of the endocrine tissue decreases rapidly during the first six months (Table 2).

Finally, in our adult controls, the values were also slightly higher than those reported in earlier studies $[8,15,20,32]$. However, this difference can be accounted for by the inclusion of isolated cells in our calculations. We also referred the proportion of endocrine tissue to the epithelial component of the pancreas excluding the mesenchymal tissue.

In a recent study performed with a similar method, Jaffe et al. [10] have obtained results comparable to those reported here. The slightly lower percentage of endocrine tissue found by these authors is probably due to the inclusion of twomonth old infants, in their group of neonates, whereas our group was limited to neonates of less than two weeks old. The results of these two studies are also in good agreement with the measurement of the insulin content of the human pancreas. Thus, from the data of Sutherland et al. [22], it can be calculated that the neonatal pancreas contains twice as much insulin per gram of tissue as the pancreas of infants (2-12 months) and ten times more than the adult pancreas.

The relative abundance of endocrine tissue in the pancreas of neonates is partly due to the poor development of the exocrine tissue. Thus, although the volume density of all endocrine cell types diminishes with aging, their total mass in the gland increases, indicating that the endocrine tissue continues to grow. However, this growth is much less marked than that of the whole pancreas ( 5 times compared to 25 times). If the total mass of endocrine pancreas is expressed in relation to body weight, one obtains, for our limited series, approximative values of 104,88 and $27 \mathrm{mg} / \mathrm{kg}$ in neonates, infants and adults, respectively. The significance of such an abundance of endocrine tissue at birth remains unclear.

From the present study it also appears that the relative proportion of the different cell types is extremely stable within each age group. This contrasts with the evolution of the endocrine cell populations with age and with the great variations in total endocrine tissue between different subjects of the same age group. Variability of the islet cell populations has been mentioned previously by Orci et al. [16]. These observations show that normal blood glucose levels are maintained throughout life by quite different masses of endocrine pancreatic tissue. They also suggest that the relative proportion of different cellular components of the pancreas may be more important than its total mass. The evolution of the endocrine populations (increase in $B$ cell and decrease in $\mathrm{D}$ cell proportions) makes it likely, however, that the interplay between the different hormones is not constant through life.

The participation of certain of these hormones in physiological processes unrelated to glucose homeostasis is an attractive, but still poorly documented possibility. The smaller number of $B$ cells in the pancreas of small for date infants [28] points to a role of insulin' in the growth of the fetus. As previously suggested [19] somatostatin might also have an impor- 
tant, and so far unrecognised, function during fetal or early extra-uterine life. The presence of numerous $\mathrm{C}$ cells, also containing somatostatin, in the thyroid of the newborn rat [1] is in keeping with this suggestion.

Finally, this study also demonstrates that small clusters of endocrine cells are present in the pancreas not only of neonates but also of infants. Thus "nesidioblastosis" may not be specific for the fetus $[12,30]$, and is not necessarily a pathognomonic feature of the pancreas of hypoglycaemic infants. Recent studies by Falkmer [7] and Jaffe et al. [10] have reached the same conclusion.

Acknowledgments. We are grateful to Miss M.-H. Desgain and Mrs S. Vandeputte-Loozen for technical assistance, to Miss C. Stenimacaitis for editorial help and to Mr J.Goossens for photographic assistance. J. C. H is "Chargé de Recherches" of the FNRS, Brussels. This study was supported by grant number 3.456081 of the FRSM, Brussels.

\section{References}

1. Alumets $\mathbf{J}$, Håkanson $\mathrm{R}$, Lundquist $\mathrm{G}$, Sundler F, Thorell J (1980) Ontogeny and ultrastructure of somatostatin and calcitonin cells in the thyroid gland of the rat. Cell Tissue Res 206: 193-201

2. Borchard F, Müntefering H (1969) Beitrag zur quantitativen Morphologie der Langerhansschen Inseln bei Früh- und Neugeborenen. Virchows Arch [Pathol Anat] 346: 178-198

3. Cardell BS (1953) Hypertrophy and hyperplasia of the pancreatic islets in new-born infants. J Pathol 66: 335-346

4. Chalkley HW (1943) Method for the quantitative morphologic analysis of tissues. J Natl Cancer Inst 4: 47-53

5. Driscoll SG, Steinke JE (1967) Pancreatic insulin content in severe erythroblastosis. Pediatrics 39: 448

6. Dubreuil G, Anderodias J (1920) Môts de Langerhans géants chez un nouveau-né issu de mère glucosurique. $\mathrm{C} R$ Soc Biol (Paris) 24: 1940-1941

7. Falkmer S, Sprik O, Vidnes J (in press) Immunohistochemical, morphometric, and clinical studies of the pancreatic islets in infants with persistent neonatal hypoglycemia of familial type with hyperinsulinism and nesidioblastosis. Acta Biol Med Germ

8. Gepts W (1958) Die histopathologischen Veränderungen der Langerhansschen Inseln und ihre Bedeutung in der Frage der Pathogenese des menschlichen Diabetes. Endokrinologie 36: 185-211

9. Heitz PU, Klöppel G, Häcki WH, Polak JM, Pearse AGE (1977) Nesidioblastosis: the pathologic basis of persistant hyperinsulinemic hypoglycemia in infants. Diabetes 26: 632-642

10. Jaffe R, Hashida Y, Yunis EJ (1980) Pancreatic pathology in hyperinsulinemic hypoglycemia of infancy. Lab Invest 42 : 356-365

11. Klöppel G, Altenähr E, Reichel W, Willig R, Freytag G (1974) Morphometric and ultrastructural studies in an infant with leucine-sensitive hypoglycemia, hyperinsulinism and islet hyperplasia. Diabetologia 10: 245-252

12. Like A, Orci L (1972) Embryogenesis of the human pancreatic islets: a light and electron microscopic study. Diabetes 21 [Supp1 2]: 511-534

13. Malaisse-Lagae F, Stefan Y, Cox J, Perrelet A, Orci L (1979)
Identification of a lobe in the adult human pancreas rich in pancreatic polypeptide. Diabetologia 17: 361-365

14. Naeye RL (1967) New observations in erythroblastosis fetalis. JAMA 200: 281-286

15. Ogilvie RF (1937) A quantitative estimation of the pancreatic islet tissue. Q J Med 6: 287-300

16. Orci L, Stefan Y, Malaisse-Lagae F, Perrelet A (1979) Instability of pancreatic endocrine cell population throughout life (Letter). Lancet I: 615-616

17. Orci L, Stefan Y, Malaisse-Lagae F, Perrelet A, Patel Y (1979) Pancreatic fat (Letter). N Engl J Med 301: 1292

18. Rahier J, Wallon J, Gepts W, Haot J (1979) Localization of pancreatic polypeptide cells in a limited lobe of the human neonate pancreas: remnant of the ventral primordium? Cell Tissue Res 200: 359-366

19. Rahier J, Wallon J, Henquin JC (1980) Abundance of somatostatin cells in the human neonatal pancreas. Diabetologia 18: 251-254

20. Saito K, Iwama N, Takahashi T (1978) Morphometrical analysis on topographical difference in size distribution, number and volume of islets in the human pancreas. Tohoku J Exp Med 124: 177-186

21. Søvik O, Vidnes J, Falkmer S (1975) Persistent neonatal hypoglycemia. Acta Pathol Microbiol Scand [A] 83: 155-166

22. Sutherland DER, Matas AJ, Steffes MW, Najarian JS (1976) Infant human pancreas: a potential source of islet tissue for transplantation. Diabetes 25: 1123-1128

23. Stemberger LR, Hardy PH, Cuculis JJ, Meyer HG (1970) The unlabeled antibody enzyme method of immunohistochemistry. Preparation and properties of soluble antigen antibody complex and its use in the identification of spirochetes. J Histochem Cytochem 18: 315-333

24. Sternberger LR (1979) Immunocytochemistry, 2nd edn. John Wiley \& Sons, New York, pp 1-354

25. Van Assche FA (1970) The fetal endocrine pancreas: a quantitative morphological approach. Thesis Katholieke Universiteit Leuven

26. Van Assche FA, Gepts W (1971) The cytological composition of the foetal endocrine pancreas in normal and pathological conditions. Diabetologia 7: 434-444

27. Van Assche FA, Gepts W, Aerts L. (1976) The fetal endocrine pancreas in diabetes (human). Diabetologia 12: 423

28. Van Assche FA, Aerts L (1979) The fetal endocrine pancreas. Contrib Gynecol Obstet 5: 44-57

29. Weibel ER (1973) Stereological techniques for electron microscopic morphometry. In: Hayat MA (ed) Principles and techniques of electron microscopy. Van Nostrand Reinhold Co, New York, p 239-296

30. Wellman KF, Volk BW, Brancato P (1971) Ultrastructure and insulin content of the endocrine pancreas in the human fetus. Lab Invest 25: 97-103

31. Wellman KF, Volk BW (1977) The islets of infants of diabetic mothers. In: Volk BW, Wellman KF (eds) The diabetic pancreas. Plenum Press, New York, p 365-380

32. Westermark P, Wilander E (1978) The influence of amyloid deposits in the islets volume in maturity onset diabetes mellitus. Diabetologia 15: 417-421

Received: 30 September 1980, and in revised form: 11 December 1980

Dr. J. Rahier

Department of Pathology

University Hospital St Luc

Av. Hippocrate, 10

B-1200 Brussels

Belgium 